\title{
Cellular Sheet Dosage Form
}

National Cancer Institute

\section{Source}

National Cancer Institute. Cellular Sheet Dosage Form. NCI Thesaurus. Code C100103.

A skin graft sheet composed of viable cells layered on a supporting substrate. 